\title{
Restoration of Damaged Ecosystem Services on Wetlands in Northern Part of the Volga-Akhtuba Floodplain (Russia)
}

\author{
A. V. Lukonina', G. Y. Klinkova², N. B. Lopantzeva ${ }^{3}$ \\ ${ }^{1}$ Botanic Garden of "Volgograd State Socio-Pedagogical University", Volgograd, Russia \\ ${ }^{2}$ Chair of Park-and-Garden and Landscape Construction of "Volgograd State Socio-Pedagogical University", \\ Volgograd, Russia \\ ${ }^{3}$ Lower Volga and Northern Caspian Region of UNDP/GEF-MNR RF Project “Mainstreaming Biodiversity \\ Conservation into Russia's Energy Sector Policies and Operations", Volgograd, Russia \\ Email: alukonina@rambler.ru, gklinkova@mail.ru, Natalya.Lopantzeva@volgawetlands.ru
}

Received 10 June 2015; accepted 18 August 2015; published 25 August 2015

\section{Abstract}

Due to the regulation of the river Volga flow, expanding of the territories intended for construction and development of agriculture wetlands Volga-Akhtuba floodplain are being significantly transformed and are losing many of their qualities. Non-regulated loads lead to the break of natural physical and chemical characteristics of water bodies, loss of biodiversity, degradation of structure and functions of biological communities and, as a result, to decreasing of potential ecosystem services. Restoration of the lost qualities of water ecosystems is a key factor in increasing sustainability of reclaimed landscapes and creating comfortable conditions for living of locals and their economic activity. On the territory of the biosphere reserve "Nature park" "Volga-Akhtuba floodplain" a number of model sites were defined in order for research projects and practical work on restoration of degraded landscapes to be executed. The widest range of the lost ecosystem qualities is being restored during work on Lake Zapornoye. Restoration of ecosystem functions is being implemented according to the main economic activities carried out in this area. Ecosystem services of the area are specified in accordance with its functional purpose. The existing landscape and ecology conditions have been studied and estimated to see if the planned ecosystem services can be provided. The project suggests the following activities: restoration of hydro-morphological characteristics, reconstruction of habitats for biodiversity and their ecosystem services, improvement to restore and preserve recreational qualities of landscape. The project includes the monitoring the effectiveness of restoration. Monitoring program is based on indices of environmental assessment.

\section{Keywords}

Restoration of Wetlands, Ecosystem Services, the Volga-Akhtuba Floodplain 


\section{Introduction}

The Volga river basin is one of the mostly developed areas in Russia. More than 60 million people live here and $45 \%$ of industry is located in this area [1].

It is well known that intensive and non-regulated anthropogenic loads affect natural physical and chemical qualities of water bodies, lead to biodiversity loss, degradation of structure and functions of biological communities and, as a result, to the reduction of potential ecosystem services from which people can benefit [2].

In the 20th century chain of power plants was built on the Volga river that drastically changed natural regime of water flow including its lower part-the Volga-Akhtuba floodplain. Being impacted by the hydrological regime change, by expanding of areas intended for building and developing agriculture in the Lower Volga valley, environmental parameters of water bodies are being transformed and many ecosystem qualities significant for people are being lost. Many shallow water bodies and eriks in the floodplain are in need of rehabilitation or full reclamation.

Restoration of water ecosystem qualities that have been lost is a key factor in improving sustainability of developed landscapes and creating comfortable conditions for living and working. Existing and potential economic activities of the area (for example, plant growing, recreation) as well as the regime of its use should be taken into consideration in restoration of degraded water bodies. It helps define range of potential ecosystem services. Estimate of the existing landscape and environmental conditions shows the possibilities of implementation of ecosystem services planned.

As world practice shows, success of this work does not only depend on state politics but also on local authorities, landowners, land users and locals who are concerned about the future of their home land and want to preserve it for their children.

Within the frames of United Nations Development Programme/Global Environment Facility and Ministry of Natural Resources of the Russian Federation (hereinafter referred to as UNDP/GEF-MNR RF) Project "Conservation of wetland biodiversity in the Lower Volga region" (2009-2013) and UNDP/GEF-MNR RF Project "Mainstreaming biodiversity conservation into Russia's energy sector policies and operations" (2014-2015) and grant program "Every drop matters" of UNDP Bureau (in Europe and CIS) and Coca-Cola Russia (2013-2015), employees of Chair of park-and-garden and landscape construction and Botany garden of Volgograd State Socio-Pedagogical University jointly with their partners managed to get research experience and practical skills in restoration of degraded wetlands and their ecosystem services. The projects were implemented by specialist from various spheres: ecology, hydrology, botanic science, zoology, ichthyology, architecture. Proposals suggested within the projects were agreed with representatives of nature protection authorities, municipal entities, land-owners, public.

\section{Condition of the Object Today}

On the territory of UNESCO biosphere reserve "Nature park" "Volga-Akhtuba floodplain” (Volgograd region) in different functional areas a number of model sites were defined for research and practical work to restore affected landscapes. Lake Zapornoye is among them.

Condition of the object today: Lake Zapornoye is located in the northern part of the Volga-Akhtuba floodplain (Figure 1). It is a typical example of degradation because of a high anthropogenic load: the water body is located near a busy road, which is surrounded by settlements and dams are built to secure the settlements in flood periods; the lands adjacent to the water body are ploughed up and are being used by locals for agriculture.

In the past during flood periods water was coming to the lake from north and south which made the lake a flowing water body and kept its sustainability. After the area used for building expanded and a highway was built the northern inflow was totally blocked and the lake no longer had streaming water that result in increasing sediments, bogging and invasion of air and aquatic plants. Based on the space image of 2002 the lake water bed in flood period had the square area of surface 30.3 ha, and in 2014 the square was 7.8 ha. Thus the lakebed area inhabited by helophytes increased from 12.1 ha to 34.3 ha (Figure 2). The water body is in critical condition because of a severe eutrophication.

Because the northern part of the lake bottom has been deepened many times, there are almost no submerged macrophytes, fauna of hydrobionts is very poor, blue-green algae is extensively developing. Fish population are rather poor in species, fish capacity is dropping.

Land vegetation is gone through a serious transformation due to a high anthropogenic load. Species tolerant to 

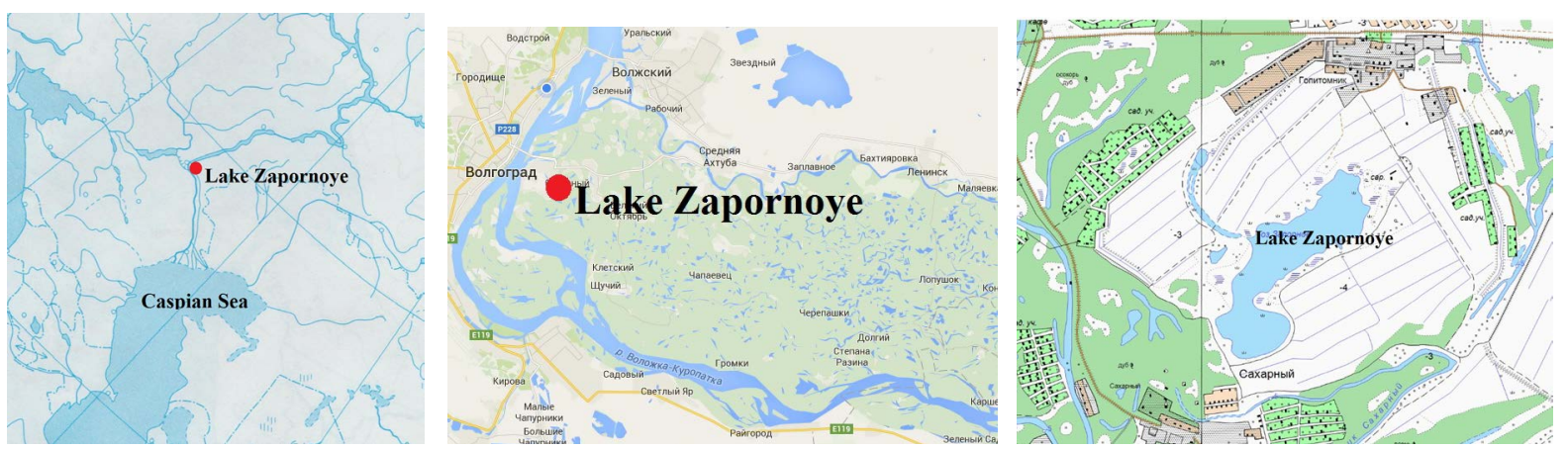

Figure 1. Lake Zapornoye.
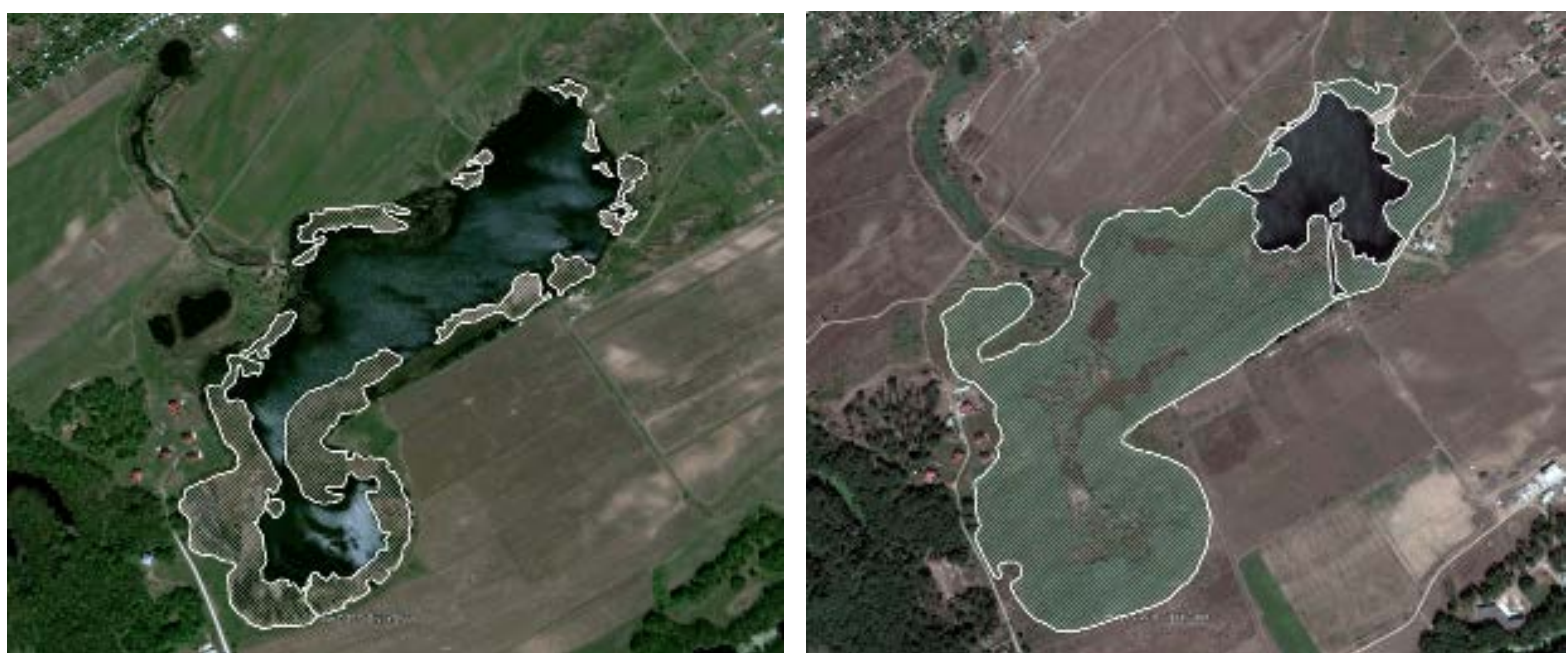

Figure 2. Area being inhabited by air and aquatic plants. Left-2002, Right-2014.

a heavy anthropogenic impact prevail. Most part of the local flora consists of adventive species which act as subdominants in some areas. Animal species of the model territory comply with those inhabiting the landscape anthropogenically affected.

Thus, Lake Zapornoye has almost lost most part of its ecosystem functions that need to be restored.

\section{Activities Planned for Landscape Reclamation}

Before you begin to format your paper, first write and save the content as a separate text file. Keep your text and graphic files separate until after the text has been formatted and styled. Do not use hard tabs, and limit use of hard returns to only one return at the end of a paragraph. Do not add any kind of pagination anywhere in the paper. Do not number text heads- the template will do that for you.

Finally, complete content and organizational editing before formatting. Please take note of the following items when proofreading spelling and grammar:

\subsection{Restoration of Hydro-Morphological Parameters}

Hydrological situation would be cardinally improved provided the lake stream capacity was restored; however, the existing constructions prevent it. Thus, there is a possibility to increase the flood water inflow into the urochische as well as increase the amount of water that is left in the lake basin after flood periods by means of restoring hydro-morphological parameters of the lake by eliminating sediments and alluvium from the lakebed.

Southern part of the lake that is almost totally filled with sediments and covered with air-and-aquatic plants needs to be deepened and, if not an open water surface, than a number of channels providing flood water inflow to the main lakebed during the flood period should be made. As an experiment special machinery partially takes out alluvium and builds "islands" with "channels" between them. Formation of this landscape will lead to in- 
creasing littoral habitats and creating a more complicated coastline, filling potential environmental niches.

\subsection{Restoration of Degraded Habitats and Biodiversity}

A number of bottom dredging works in the northern part of the lake resulted in a simpler morphology of the lakebed: the coastline is straight; the area of shallow water is minimized, deep water areas are growing fast. These factors lead to a fast reduction of diversity of habitats for all biological groups and because of that the ecosystem condition is estimated as very low.

The functioning of the ecosystem is improved and the lost functions are restored by increasing the angularity of the coastline and creating shallow waters of various types by means of land work. This will improve biodiversity indicators and influence the water quality. In order to restore the habitats species typical for the VolgaAkhtuba floodplain are introduced there (the plants were cultivated in Wild flora nursery of VSSTTU Botanic garden).

In accordance with environmental conditions of the landscape to be restored, flood water level restore trees and bushes, floodplain meadow communities, littoral submerged vegetation and helophyte communities.

Trees and bushes support specific groups of dendrophwl biota. In the process of restoration by planting local species dendroflora species are increased that will help attract various birds and insects.

Meadows support a significant group of biodiversity. They determine the typical image and esthetics of the valley, having been formed in specific conditions of the Volga-Akhtuba floodplain. Meadows are very diverse in species and inhabited by plants from different ecological groups. That is why, besides introducing plants on specially prepared sites [3], restoration of vegetation communities includes also replenishing soil with seeds that will provide a complete pool of species by means of distributing hay and seed dust [4]. This technology includes preparation of hay with genesic organs on donor sites in several stages and distributing it in the areas to be restored.

Coastal (air-and-aquatic) plants are habitats for a large group of invertebrate animals and serve as food for phytophilous fish. Because the lake is invaded by air-and-aquatic vegetation (mainly by Phragmites australis (Cav.) Trin.ex Steud. (P. communis Trin.)) spawning areas for phytophilous fish are significantly decreasing as well as the fish growing area, this also affects development of plankton and bottom living organisms which are the main food for fish, and it also affects oxygen regime. In this connection work is being executed to reduce the lake bed area covered by high helophytes in compliance with protective regime of the biosphere reserve: such as biological reclamation that is introducing herbivorous fish into the lake; mechanical elimination of the vegetation by means of mowing; chemical cultivation using herbicides allowed in Russia to be used in water conservation area of fish farming water bodies. Other helophyte species that are more attractive for hydrobionts are introduced in the habitats to substitute for the eliminated species.

More functional connections of invertebrate hydrobionts being the main food for fish can be traced in associations of submerged soft vegetation. In Lake Zapornoye this phytocenosis is located in small areas. Restoration is done by introducing seeds and primordiums of submerged water plants typical for the Volga-Akhtuba floodplain.

\subsection{Territory Improvement for Better Recreational Characteristics of the Landscape}

After the bridge over the Volga river was put into operation, recreational load on the floodplain ecosystems started growing very fast. Non-regulated recreational activities result in degradation of the northern part of the floodplain, including Lake Zapornoye which has always been significantly affected by the main highway and close location to Volgograd. One of the ways out from this serious situation is creating specially equipped and recreationally attractive recreation areas with supervised access. Lake Zapornoye can serve as a model area.

Recreational improvement of the territory is making the landscape of this area attractive by means of creating esthetically attractive scenery with the help of vegetation and creating recreational infrastructure. Ecological landscape project of the territory is elaborated to carry out the work within Lake Zapornoye water conservation zone in accordance with recommendations on restoration of biodiversity of aquatic and semi-aquatic plants, hydrobionts and ichthyofauna with the existing anthropogenic load and economic use. To make the landscape more attractive landscape groups were created, structure of the area was made more complicated, the number of ornamental wild plants was increased, habitats for song birds and insects were created. Recreational infrastructure elements were designed (bridges, ramps) as well as viewing spots, beach areas.

Possible positive impact of the activities planned on ecosystem services on Lake Zapornoye is given in Table 1. 
Table 1. Plan for restoring ecosystem services.

\begin{tabular}{|c|c|c|c|c|c|c|c|}
\hline \multirow{2}{*}{$\begin{array}{l}\text { Ecosystem services } \\
\text { under } \\
\text { restoration/activities } \\
\text { planned }\end{array}$} & \multirow{2}{*}{$\begin{array}{l}\text { Improving } \\
\text { hydromorphological } \\
\text { parameters and } \\
\text { water supply }\end{array}$} & \multirow[b]{2}{*}{$\begin{array}{l}\text { Creating } \\
\text { habitats }\end{array}$} & \multicolumn{5}{|c|}{ Restoration of plant communities } \\
\hline & & & $\begin{array}{c}\text { Communities } \\
\text { of trees } \\
\text { and bushes }\end{array}$ & $\begin{array}{c}\text { Elevated } \\
\text { meadows }\end{array}$ & $\begin{array}{c}\text { Medium } \\
\text { level } \\
\text { meadows }\end{array}$ & $\begin{array}{c}\text { Low } \\
\text { level } \\
\text { meadows }\end{array}$ & $\begin{array}{c}\text { Submerged } \\
\text { littoral } \\
\text { vegetation }\end{array}$ \\
\hline \multicolumn{8}{|l|}{ Providing } \\
\hline \multicolumn{8}{|l|}{ Food } \\
\hline For people & & & ++ & & + & ++ & ++ \\
\hline For domestic animals & & & & + & ++ & & \\
\hline Fresh water (capacity) & +++ & + & & & & & \\
\hline Wood (firewood) & & + & + & & & & \\
\hline Genetic resources & & & + & + & + & + & + \\
\hline \multicolumn{8}{|l|}{ Regulating } \\
\hline $\begin{array}{l}\text { Microclimate } \\
\text { regulation }\end{array}$ & +++ & +++ & +++ & & & ++ & \\
\hline \multicolumn{8}{|l|}{ Water regulation } \\
\hline Water purification & & & & & + & + & +++ \\
\hline Pollination & & & +++ & +++ & ++ & + & \\
\hline \multicolumn{8}{|l|}{ Supporting } \\
\hline Soil-formation & & & ++ & ++ & ++ & & \\
\hline Substance circulation & & & ++ & ++ & ++ & ++ & ++ \\
\hline \multicolumn{8}{|l|}{ Cultural } \\
\hline Recreation & +++ & & +++ & + & ++ & ++ & ++ \\
\hline Tourism & + & +++ & & & ++ & ++ & ++ \\
\hline Educational & & & ++ & ++ & ++ & ++ & ++ \\
\hline Comfort and esthetics & + & ++ & +++ & & + & + & \\
\hline
\end{tabular}

Pre-project, current and post-project monitoring activities are planned. Monitoring programme is based on environmental indicators elaborated in the region. It is aimed at estimating the effectiveness of work on restoration and further management of the area.

The results of this research and practice work have a great significance for creating practice of restoring degraded ecosystems of the Lower Volga.

\section{References}

[1] Klinkova, G.Yu., Selischeva, V.A. and Planeta, M. (2011) Nature Complexes and Biodiversity of the Lower Volga: Workbook, Elaborated, Published and Distributed Free of Charge within the Frames of the UNDP/GEF-MNR RF Project “Conservation of Wetland Biodiversity in the Lower Volga Region” with Financial Support of Global Environmental Facility, 256.

[2] Millennium Ecosystem Assessment (2005) Ecosystems and Human Well-Being. Synthesis Report, Island Press, Washington DC, 160.

[3] Klinkova, G.Yu., Lukonina, A.V., Planeta, M., et al. (2014) Restoration of Floodplain Forest Ecosystems: Study Guide Published within the Frames of the UNDP/Coca-Cola Grant Project "Every Drop Matters”. 128.

[4] Dzybov, D.S. (2001) Agrosteppe Method: Fast Restoration of Natural Vegetation. Study Guide. Publishing House Nauchnaya kniga, Saratov, 40. 